\title{
Penerapan Model Auditory Intelectually Repetition untuk Meningkatkan Pemahaman Matematis Berbantuan Media Roda Pintar Matematika
}

\author{
Soviana Aprilia $^{1 \bowtie}$, Henry Suryo Bintoro ${ }^{2}$ dan Jayanti Putri Purwaningrum ${ }^{3}$ \\ ${ }^{1}$ SD N Sukobubuk 01 \\ ${ }^{2,3}$ Prodi Pendidikan Matematika, Universitas Muria Kudus
}

\begin{abstract}
Info Artikel Abstract
Sejarah Artikel:

Diterima 6 Mei 2020

Direvisi 12 Mei 2020

Disetujui 15 Mei 2020

Keywords:

Mathematical

Understanding Skill,

Auditory Intellectualy

Repetition, Mathematical

Smart Wheel.

Paper type:

Research paper

The purpose of this study is to improve the ability of mathematical understanding, learning activities and teaching skills of teachers through the Auditory Intellectualy Repetition model with assisted by the mathematical smart wheel media. This research is a classroom action research conducted in class IV SDN Sukobubuk 01 Margorejo District Pati Regency second semester 2019/2020 academic year. The research method uses classroom action research consisting of 2 cycles each cycle consisting of 4 stages namely planning, implementing, observing and reflecting. The instruments used in this study were tests of mathematical understanding abilities, observation sheets of student learning activities and teacher teaching skills. Data will be analize test used in this research is quantitative and qualitative data analysis. The results showed, among others: (1) The ability of mathematical understanding through the Auditory Intellectualy Repetition Model assisted by the mathematical smart wheel media increased by 30.29 from the initial condition of 43.35 to 73.64 in the final condition; (2) Student learning activities through the Auditory Intellectualy Repetition Model assisted by mathematical smart wheel media have increased by 23.13 from the initial conditions of 53.12 to 76.25 in the final conditions; (3) Teachers' teaching skills in applying the Auditory Intellectualy Repetition Model assisted by the mathematical smart wheel media increased by 23.5 from the initial conditions of 52.5 to 76 in the final condition
\end{abstract}

\begin{abstract}
Abstrak
Tujuan penelitian ini adalah untuk meningkatkan kemampuan pemahaman matematis, aktivitas belajar dan keterampilan mengajar guru melalui model Auditory Intellectualy Repetition berbantuan media roda pintar matematika. Penelitian ini merupakan penelitian tindakan kelas yang dilakukan di kelas IV SDN Sukobubuk 01 Kecamatan Margorejo Kabupaten Pati semester II tahun pelajaran 2019/2020. Metode penelitian menggunakan penelitian tindakan kelas yang terdiri dari 2 siklus masing-masing siklus terdiri dari 4 tahapan yaitu perencanaan, pelaksanaan, pengamatan dan refleksi. Instrumen yang digunakan dalam penelitian ini adalah tes kemampuan pemahaman matematis, lembar observasi aktivitas belajar siswa dan keterampilan mengajar guru. Teknik analisis data yang digunakan dalam penelitian ini adalah analisis data kuantitatif dan kualitatif. Hasil penelitian menunjukkan antara lain: (1) Kemampuan pemahaman matematis melalui Model Auditory Intellectualy Repetition berbantuan media roda pintar matematika mengalami peningkatan sebesar 30,29 dari kondisi awal 43,35 menjadi 73,64 pada kondisi akhir; (2) Aktivitas belajar siswa melalui Model Auditory Intellectualy Repetition berbantuan media roda pintar matematika mengalami peningkatan sebesar 23,13 dari kondisi awal sebesar 53,12 menjadi 76,25 pada kondisi akhir; (3) Keterampilan mengajar guru dalam menerapkan Model Auditory Intellectualy Repetition berbantuan media roda pintar matematika mengalami peningkatan sebesar 23,5 dari kondisi awal sebesar 52,5 menjadi 76 pada kondisi akhir.
\end{abstract}

(C) 2020 Universitas Muria Kudus

\footnotetext{
Alamat korespondensi:

Program Studi Pendidikan Matematika

Fakultas Keguruan dan Ilmu Pendidikan Universitas Muria Kudus

Kampus UMK Gondangmanis, Bae Kudus Gd. L. 1t I PO. BOX 53 Kudus

Tlp (0291) 438229 ex.147 Fax. (0291) 437198

E-mail: soviana.aprilia@gmail.com
}

p-ISSN 2615-4196 


\section{PENDAHULUAN}

Masalah yang sering dihadapi dalam sebuah pembelajaran matematika adalah terkait prestasi belajar siswa. Ada beberapa faktor yang mempengaruhi prestasi belajar siswa dalam pembelajaran matematika salah satunya adalah kemampuan pemahanam matematis siswa dalam memahami materi yang dipelajari. Kemampuan pemahaman matematis siswa yang rendah mempengaruhi prestasi belajar siswa itu sendiri. Ada beberapa hal yang dapat menyebabkan rendahnya kemampuan pemahaman matematis siswa diantaranya adalah lingkungan belajar, media atau alat pembelajaran yang digunakan, serta metode pembelajaran yang diterapkan guru dalam sebuah pembelajaran.

Hal tersebut sesuai dengan hasil wawancara guru Kelas IV dan observasi yang dilakukan oleh peneliti di SDN Sukobubuk 01 Margorejo Pati yang menyebutkan bahwa salah satu masalah yang dihadapi guru dalam pembelajaran matematika adalah kemampuan pemahaman matematis siswa yang masih rendah. Hal tersebut disebabkan oleh beberapa faktor antara lain adalah kurangnya media yang tersedia di sekolah tersebut, serta penggunaan model dan metode pembelajaran yang monoton sehingga siswa cenderung pasif dalam pembelajaran. Hasil wawancara tersebut diperkuat dengan observasi yang dilakukan oleh peneliti. Saat pembelajaran matematika berlangsung siswa cenderung pasif, kurang memperhatikan penjelasan guru dan tidak bersemangat. Beberapa kali guru menjelaskan namun siswa masih belum paham dengan materi yang disampaikan.

Informasi lain yang didapat dari wawancara dengan guru kelas IV SDN Sukobubuk 01 adalah kemampuan siswa yang rendah dalam mengerjakan soal matematika dalam bentuk soal cerita dengan tingkat kesulitan soal sedang hingga tinggi. Hal tersebut terlihat dari rata-rata hasil prasiklus yang menunjukkan bahwa kemampuan pemahaman siswa masih rendah yaitu 43,35. Siswa masih kesulitan dalam memahami dan menjawab soal dalam bentuk cerita yang sudah disesuaikan dengan indikator pemahaman matematis.

Ada beberapa indikator pemahaman matematis, Sumarmo (dalam Purwaninngrum, 2018:4) menjelaskan terdapat 4 indikator pemahaman matematis, yaitu: (1) pemahaman mekanikal, yaitu dapat mengingat dan menerapkan sesuatu secara rutin atau perhitungan sederhana; (2) pemahaman induktif, yaitu dapat mencobakan sesuatu dalan kasus sederhana dan tahu bahwa sesuatu itu berlaku dalam kasus serupa; (3) pemahaman rasional, yaitu dapat membuktikan kebenaran sesuatu; (4) dan pemahaman intuitif, yaitu dapat memperkirakan kebenaran sesuatu tanpa ragu-ragu sebelum menganalisis secara analitik. Minarni, Napitupulu, dan Husein (2016:44) menjelaskan bahwa pemahaman matematis sangat penting dalam belajar matematika karena akan memudahkan seseorang untuk memecahkan masalah matematika.

Salah satu upaya untuk mengatasi masalah tersebut adalah dengan menggunakan metode pembelajaran yang sesuai dan menggunakan media yang tepat. Sehingga pembelajaran akan berjalan lebih efektif, membuat pembelajaran lebih menyenangkan dan akan membuat siswa aktif dalam pembelajaran. Untuk meningkatkan kemampuan pemahaman matematis siswa dan membuat siswa lebih aktif peneliti menerapkan model pembelajaran Auditory Intellectualy Repetition.

Model Auditory Intellectualy Repetition merupakan salah satu model pembelajaran kooperatif. Siswa dituntut lebih aktif dalam berbicara dan berpikir untuk memperdalam dan memperluas pemahaman siswa melalui pengerjaan soal dan pemberian tugas atau kuis. Manurung (2016:100) menyatakan bahwa suatu pembelajaran akan efektif jika memperhatikan tiga hal, yaitu Auditory, Intellectually, dan Repetition. Hasnawati, Ikmam dan Sari (2016:250) menjelaskan Auditory berarti indera telinga digunakan dalam belajar dengan cara menyimak, berbicara, presentasi, argumentasi, dan menanggapi. Intellectually berarti kemampuan berpikir perlu dilatih melalui latihan bernalar, mencipta, memecahkan masalah. Repetition berarti pengulangan melalui pengerjaan soal, pemberian tugas dan kuis.

Sintaks atau langkah-langkah model pembelajaran Auditory Intellectualy Repetition sebagai berikut (Shoimin, 2017:30): (1) Siswa dibagi menjadi beberapa kelompok, masingmasing kelompok terdiri dari 4-5 anggota; (2) Siswa mendengarkan dan memperhatikan penjelasan dari guru; (3) Setiap kelompok mendiskusikan tentang materi yang mereka pelajari dan menuliskan hasil diskusi tersebut dan selanjutnya untuk dipresentasikan di depan kelas (auditory); (4) Saat diskusi berlangsung, siswa mendapat soal atau permasalahan yang berkaitan dengan materi; (5) Masing-masing kelompok memikirkan cara menerapkan hasil diskusi serta dapat meningkatkan kemampuan mereka untuk menyelesaikan masalah (intellectual); (6) Setelah selesai berdiskusi, siswa mendapat pengulangan materi dengan cara mendapatkan tugasa atau kuis untuk setiap individu (repetition). 
Peneliti memilih model Auditory Intellectualy Repetition karena siswa lebih banyak memiliki kesempatan untuk berlatih dalam menjawab pertanyaan sehingga siswa akan lebih memahami materi yang dipelajari, siswa dapat merespon pertanyaan dengan cara mereka sendiri, dan lebih banyak memiliki kesempatan untuk memanfaatkan pengatahuan dan keterampilan secara komprehensif.

Agar pembelajaran lebih menyenangkan, peneliti melengkapinya dengan menggunakan media roda pintar matematika. Media roda pintar matematika ini merupakan media yang diadopsi dari permainan roda putar. Yunniartien (2017:16) menyatakan bahwa media roda pintar adalah media pembelajaran yang menggunakan permainan roda putar (twister). Roda pintar metamatika merupakan media berbasis permainan yang memiliki nilai edukatif. Dengan media ini siswa akan belajar sambil bermain agar siswa tidak bosan dalam mengikuti pembelajaran. Media roda pintar matematika ini memiliki keunggulan yaitu menarik dan mudah digunakan.

Dengan menggunakan model Auditory Intellectualy Repetition dengan berbantuan media roda pintar matematika diharapkan kemampuan pemahaman matematis siswa dapat meningkat. Dengan penggunaan model pembelajaran Auditory Intellectualy Repetition yang memiliki tujuan memperdalam materi yang dipelajari dengan cara pemberian latihan soal ataupun kuis dengan disertai perminan roda pintar matematika yang menarik sekaligus selingan untuk mendapatkan soal diharapkan dapat menarik minat siswa dalam belajar sehingga siswa lebih aktif dan dapat meningkatkan pemahaman matematis siswa.

Berdasarkan uraian diatas, maka rumusan masalah dalam penelitian ini adalah: (1) Bagaimana peningkatan kemampuan pemahaman matematis siswa kelas IV SDN Sukobubuk melalui model Auditory Intellectualy Repetitiondengan berbantuan media roda pintar matematika pada materi Keliling dan Luas Bangun Datar?; (2) Bagimana aktivitas belajar siswa kelas IV SDN Sukobubuk melalui model Auditory Intellectualy Repetition dengan berbantuan media roda pintar matematika pada materi Keliling dan Luas Bangun Datar?; (3) Bagaimana keterampilan mengajar guru dalam meningkatkan kemampuan pemahaman matematis siswa kelas IV SDN Sukobubuk 01 melalui model Auditory Intellectualy Repetition dengan berbantuan media roda pintar matematika pada materi Keliling dan Luas Bangun Datar?

Tujuan penelitian ini adalah untuk: (1) peningkatan kemampuan pemahaman matematis siswa melalui model pembelajaran Auditory Intellectualy Repetition dengan berbantuan media roda pintar matematika ; (2) peningkatan aktivitas belajar siswa dalam pembelajaran matematika; (3) peningkatan keterampilan mengajar guru dalam menerapkan model pembelajaran Auditory Intellectualy Repetition dengan berbantuan media roda pintar matematika.

\section{METODE PENELITIAN}

Penelitian ini merupakan penelitian tindakan kelas yang dilakukan di SDN Sukobubuk 01, kecamatan Margorejo, Kabupaten Pati pada semester II tahun pelajaran 2019/2020. Penelitian tindakan kelas ini terdiri dari 2 siklus yang masing-masing siklus terdiri dari 4 tahapan yaitu perencanaan, pelaksanaan, pengamatan dan refleksi. Subjek penelitian berjumlah 17 siswa yang terdiri dari 4 siswa laki-laki dan 13 siswa perempuan.

Penelitian tindakan kelas ini dilaksanakan mulai bulan september 2019 sampai maret 2020 . Langkah awal yang disiapkan dalam penelitian ini adalah mempersiapkan proposal dan isntrumen penelitian pada bulan September sampai November 2019 dilanjutkan pelaksanaan pembelajaran siklus I dan siklus II pada bulan Januari 2020 dan dilanjutkan penyusunan laporan pada bulan Februari sampai Maret 2020.

Teknik pengumpulan data yang digunakan dalam penelitian ini adalah teknik tes dan non tes. Tes yang dilakukan adalah tes kemampuan pemahaman matematis yang dilaksanakan setiap akhir siklus, dan non tes yang dilakukan adalah pengamatan, wawancara dan dokumentasi. Teknik analisis yang digunakan adalah teknik analisis data kuantitatif dan kualitatif. Teknik analisis data kuantitatif digunakan untuk menghitung rata-rata nilai kelas dan ketuntasan belajar. Sedangkan teknik analisis data kualitatif digunakan untuk manganalisis hasil observasi aktivitas belajar siswa dan keterampilan mengajar guru.

\section{HASIL DAN PEMBAHASAN}

\section{Kemampuan Pemahaman Matematis Siswa}

Untuk mengatahui kondisi awal subjek penelitian, peneliti melakukan prasiklus yang dilakukan sebelum penelitian. Tujuan dari prasiklus ini adalah untuk mengetahui kemampuan pemahaman matematis siswa yang dilakukan dengan pemberian soal prasiklus, peneliti juga melakukan pengamatan aktivitas belajar dan keterampilan mengajar guru untuk mengetahui bagaimana proses pembelajaran yang berlangsung, serta mengetahui permasalahan yang dihadapi guru maupaun siswa dalam pembelajaran 
matematika melalui wawancara. Dari hasil analisis data prasiklus menunjukkan bahwa kemampuan pemahaman matematis siswa masih rendah. Setelah memperoleh hasil data hasil prasiklus kemampuan pemahaman matematis siswa selanjutnnya dilakukan penelitian siklus I dan II. Berikut perbandingan hasil tes kemampuan pemahaman matematis siswa pada kondisi awal (prasiklus) dengan kondisi akhir (siklus II), disajikan pada Tabel 1 berikut.

Tabel 1. Hasil Prasiklus Kemampuan Pemahaman Matematis Siswa

\begin{tabular}{ccc|c}
\hline No & Keterangan & $\begin{array}{c}\text { Kondisi } \\
\text { Awal }\end{array}$ & $\begin{array}{c}\text { Kondisi } \\
\text { Akhir }\end{array}$ \\
\hline 1 & Nilai tertinggi & 53 & 100 \\
\hline 2 & $\begin{array}{c}\text { Nilai } \\
\text { Terendah }\end{array}$ & 18 & 31 \\
\hline 3 & Rata-rata & 43,35 & 73,64 \\
\hline 4 & Siswa Tuntas & 0 & 14 \\
\hline 5 & $\begin{array}{c}\text { Siswa Belum } \\
\text { Tuntas }\end{array}$ & 17 & 3 \\
\hline
\end{tabular}

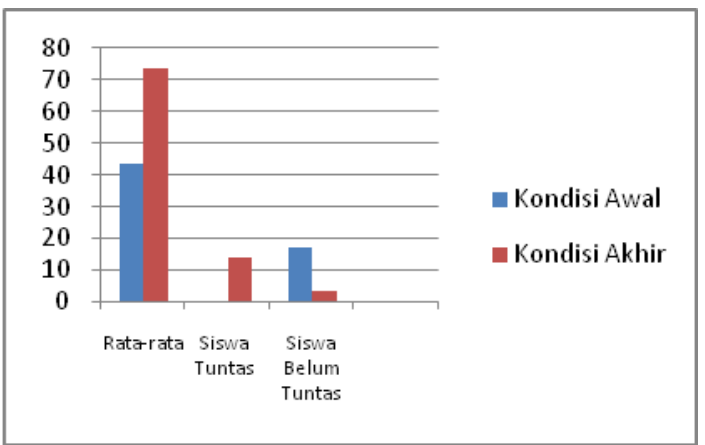

Gambar 1. Perbandingan hasil pemahaman matematis siswa kondisi awal dan kondisi akhir

Setelah dilakukan penelitian dengan menerapkan model Auditory Intellectualy Repetition berbantuan media roda pintar matematika Kemampuan pemahaman matematis siswa mengalami peningkatan 30,29 yang ditunjukkan dengan rata-rata nilai siswa dari kondisi awal 43,35 menjadi 73,64 pada kondisi akhir. Peningkatan kemampuan pemahaman matematis ini dipengaruhi oleh beberapa faktor. Salah satunya adalah pemilihan model pembelajaran yang tepat dengan menerapkan model pembelajaran AIR. Hal tersebut sependapat dengan Wijaya (2018:27) yang menyatakan bahwa model AIR efektif digunakan untuk meningkatkan pemahaman matematis siswa.

Sesuai dengan pendapat Shoimin (2017:30) Model AIR memiliki kelebihan antara laian: (1) Siswa lebih berpartisipasi aktif dalam pembelajaran dan sering mengekspresikan idenya; (2) Siswa memiliki kesempatan lebih banyak dalam memanfaatkan pengetahuan dan keterampilan secara komprehensif; (3) Siswa dengan kemampuan rendah dapat merespons permasalahan dengan cara mereka sendiri; (4) Siswa secara intrinsik termotivasi untuk memberikan bukti atau penjelasan; (5) Siswa memiliki pengalaman banyak untuk menemukan sesuatu dalam menjawab pertanyaan.

Selain pemilihan model pembelajaran yang tepat, penggunaan media pembelajaran roda pintar matematika juga sangat mempengaruhi keberhasilan pebelajaran. Siswa sangat antusias saat bermain media tersebut. Dengan bantuan media pembelajaran yang tepat pembelajaran akan berjalan lebih efektif dan menyenangkan sehingga kompetensi yang diharapkan dapat tercapai. Hal tersebut sependapat dengan Mujiani (2016:200) menjelaskan bahwa media pembelajaran yang tepat dan sesuai yang disajikan guru sangat membantu siswa dalam dalam mencapai kompetensi dasar pada pelajaran matematika.

\section{Aktivitas Belajar Siswa}

Untuk mengatahui kondisi awal bagaimana aktivitas siswa dalam pembelajaran peneliti melakukan pengamatan prasiklus. Setalah peneliti mendapat data dan gambaran mengenai aktivitas belajar siswa kemudian pengamatan dilanjutkan ke siklus I dan siklus II. Berikut hasil pengamatan aktivitas belajar siswa pada kondisi awal dan kondisi akhir disajikan pada Tabel 2.

Tabel 2. Hasil Pengamatan Aktivitas Belajar Siswa

\begin{tabular}{ccc}
\hline Uraian & Kondisi Awal & Kondisi Akhir \\
\hline Rata-rata & & \\
Aktivitas & 53,12 & 76,25 \\
Belajar & & \\
Siswa & & \\
\hline
\end{tabular}

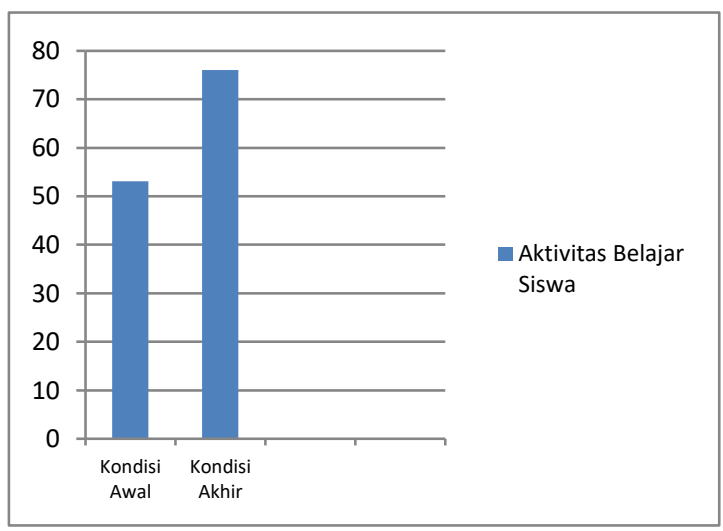

Gambar 2. Perbandingan aktivitas belajar siswa kondisi awal dan kondisi akhir

Dari Tabel 2 dan Gambar 2 diketahui aktivitas belajar mengalami peningkatan sebesar 
23,13 dilihat dari rata-rata nilai aktivitas belajar siswa dari kondisi awal 53,12 menjadi 76,25 pada kondisi akhir. Hal ini membuktikan bahwa penerapan model pembelajaran AIR berbantuan media roda pintar metematika dapat meningkatkan aktivitas belajar siswa kelas IV SDN Sukobubuk 01 semester I tahun pelajaran 2019/2020.

Indikator pengamatan aktivitas belajar siswa meliputi 8 indikator menurut Sardiman (dalam Nurmala, 2014:5), yaitu visual activities, oral activities, listening activities, writing activities, motor activities, mental activities, dan emosional activities.

\section{Keterampilan Mengajar Guru}

Pengamatan keterampilan mengajar guru bertujuan untuk mengetahui kemampuan guru dalam mengajar. Dalam penelitian ini yang menjadi subjek penelitian keterampilan mengajar guru adalah peneliti itu sendiri dengan bantuan observer yaitu guru kelas. Ada 9 indikator yang digunakan dalam pengamatan keterampilan mengajar guru menurut Hasibuan dkk (dalam Iriyani, 2008;280) yaitu: keterampilan membuka pelajaran, keterampilan bertanya, keterampilan menjelaskan, keterampilan mengadakan variasi, keterampilan mengelola kelompok, keterampilan mengajar kelompok kecil dan perorangan, keterampilan memimpin diskusi kelompok kecil, keterampilan memberi penguatan, keterampilan menutup pelajaran. Berikut hasil pengamatan keterampilan mengajar guru pada pada kondisi awal dan kondisi akhir disajikan pada Tabel 3.

Tabel 3. Hasil Pengamatan keterampilan mengajar

\begin{tabular}{ccc} 
guru & & \\
\hline Uraian & Kondisi Awal & Kondisi Akhir \\
\hline $\begin{array}{c}\text { Rata-rata } \\
\text { keterampilan } \\
\text { mengajar } \\
\text { guru }\end{array}$ & 52,5 & 76 \\
\hline
\end{tabular}

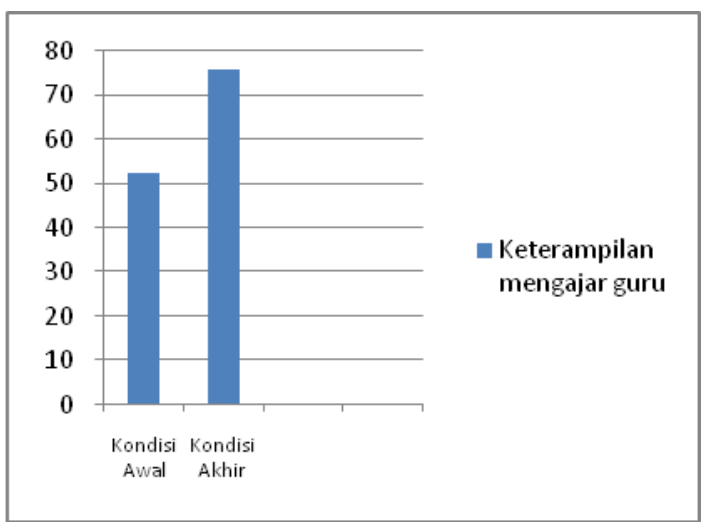

Gambar 3. Perbandingan keterampilan mengajar kondisi awal dan kondisi akhir
Dari penjelasan diatas, diketahui bahwa keterampilan mengajar guru mengalami peningkatan sebesar 23,5 dilihat dari rata-rata keterampilan mengajar guru dari kondisi awal 52,5 menjadi 76 pada kondisi akhir. Keterampilan mengajar guru mengalami peningkatan dalam menerapkan model pembelajara AIR berbantuan media roda pintar matematika pada meteri keliling dan luas bangun datar. Indikator keberhasilan sudah tercapai sehingga penelitian dihentikan pada siklus II. Hal ini membuktikan bahwa pada kondisi akhir kemampuan pemahaman matematis, aktivitas belajar siswa, dan keterampilan mengajar guru dapat ditingkatkan dan telah mencapai target penelitian setelah diterapkannya model AIR berbantuan media roda pintar matematika pada materi keliling dan luas bangun datar.

\section{SIMPULAN}

Berdasarkan hasil penelitian dan pembahasan yang telah diuraikan dapat disimpulkna bahwa (1) Kemampuan pemahaman matematis siswa kelas IV SDN Sukobubuk 01 mengalami peningkatan dan telah mencapai indikator keberhasilan yaitu mencapai KKM dengan ketuntasan klasikal lebih dari $75 \%$ dengan minimal jumlah siswa tuntas adalah 13 siswa; (2) Aktivitas belajar siswa kelas IV SDN Sukobubuk 01 mengalami peningkatan. Dan telah mencapai KKM dengan ketuntasan klasikal lebih dari $75 \%$ dengan minimal jumlah siswa tuntas adalah 13 siswa; (3) Keterampilan mengajar guru mengalami peningkatan dan telah mencapai indikator keberhasilan dengan persentase lebih dari sama dengan $70 \%$ dengan minimal masuk dalam kategori terampil.

\section{DAFTAR PUSTAKA}

Hasnawati, Ikmam dan Astuti Sari. 2016. EfectivenesModel of Auditory Intellectualy Repetition to Learning Outcomes of Math Student. International Journal of Education and Research. 4 (5): 250.

Iriyani, Dwi. 2008. Pengembangan Supervisi Klinis untuk Meningkatkan Keterampilan Mengajar Guru. Didaktika, 2 (2): 280.

Manurung, Sri Hariani. 2016. Upaya Meningkatkan Kreativitas dan Hasil Belajar Metamatika Siswa dengan Menggunakan Model AIR (Auditory, Intellectually, Repetition) Pada Siswa Kelas VIII MTs Negeri Rantauprapat Tahun Pelajaran 2014/2015. Jurnal EduTech, 2 (1): 100. 
Minarni A, Napitulu EE, dan Husein Rahmad. 2016. Mathematical Understanding And Representation Ability Of Public Junior HighSchool In North Sumatra. Journal on Mathematics Education. 7 (1): 44.

Mujiani, Dwi safitri. 2016. Pengaruh Media Pembelajaran dan Kecerdasan Logis Matematis Terhadap Hasil Belajar Matematika Siswa. Jurnal Pendidikan Dasar. 7 (2): 199-209.

Nurmala, Desy Ayu dkk. 2014. Pengaruh Motivasi Belajar dan Aktivitas Belajar Tehadap Hasil Belajar Akuntansi. Jurnal Pendidikan Ekonomi Undiksha, 4 (1): 4-5.

Purwaningrum, Jayanti Putri. 2018. Pakem Matematika. Kudus: Universitas Muria Kudus.

Shoimin, Aris. 2017. 68 Model Pembelajaran Inovatif dalam Kurikulum 2013. Yogyakarta: Ar-Ruzz Media.

Wijaya dkk. 2018. Analisis Kemampuan Pemahaman Matematis Siswa Kelas X Pada Materi Bangun Ruang. UNION: Jurnal Pendidikan Matematika, 6 (1): 1928.

Yunniartien, Ersa. 2017. Penggunaan Media Roda Pintar untuk Meningkatkan Hasil Belajar Matematika Materi Keliling dan Luas Segitiga Kelas IV SDN 1 Dasan Tereng Tahun Ajaran 2017/2018. PGSD Universitas Mataram 
Soviana Aprilia, Henry Suryo Bintoro dan Jayanti Putri Purwaningrum Anargya: Jurnal Ilmiah Pendidikan Matematika, Vol. 3 No.1, April 2030 